\section{Gunny bag based soil columns for crop diversification in rice field to enhance livelihood security of land scarce farmers}

\author{
A. K. Ghorai, D. K. Kundu, Shailesh Kumar, \\ A. Shamna and Debarati Datta* \\ ICAR-Central Research Institute for Jute and Allied Fibres, \\ Barrackpore 700 120, India
}

Crop diversification in waterlogged rice field using gunny bag based soil columns produced 3-4 tonnes of kharif rice, 4.5-5.4 tonnes of rabi rice along with other vegetable crops worth $\mathrm{Rs} \mathbf{0 . 5}-\mathbf{3 . 0}$ lakh/ha with higher $B$ : C ratio for cucurbits. Crop diversification in rice field using gunny bag/hessian based soil columns increased cropping intensity by $100-200 \%$, generated additional returns and increased employment opportunities. In this process, nearly 1500 to 5000 number of gunny bags (capacity $50 \mathrm{~kg}$ ) can be used per hectare rice land in an economical manner. Even if $1.0 \%$ $(0.4 \mathrm{M} \mathrm{ha})$ of the total rice acreage in India and Bangladesh (40 M ha) is diversified, about 10 lakh tonnes jute fibre will be utilized. It will increase the marketing opportunities of raw jute fibre, provide nutritional and livelihood security to resource-poor farmers.

Keywords: Crop diversification, economic benefit, gunny bag, vegetable production, waterlogged rice field.

RICE low lands limit cultivation of vegetables or other dicots in them owing to its anaerobic nature. Profitable crop diversification in waterlogged rice land using gunny bag/hessian reinforced soil columns avoiding anoxia, has opened up new vistas which will strengthen resource-poor rice farmers' economy of South East Asian countries. Water is quickly drained off from soil columns by gravity and lateral flows owing to its meshy nature. Experiments were conducted in kharif and rabi seasons of 2011 to 2017, at ICAR-Central Research Institute for Jute and Allied Fibres (ICAR-CRIJAF), Barrackpore, India, main farm and demonstrations were also made in some selected farmers' fields in West Bengal (North 24 Parganas, Hooghly, Murshidabad, West Midnapur and Jhargram). Gunny bag/hessian reinforced soil columns of varied dimensions $(22.5-45 \mathrm{~cm}$ in height and $45 \mathrm{~cm}$ diameter) were developed in waterlogged rice field to grow vegetable crops avoiding anoxia. The hydrograph of ponding varied from 0 to $30 \mathrm{~cm}$ during rice growth. In kharif ricevegetable relay system, yield of rice was 3-4t/ha (fine rice cv. Banskati and Satabdi) along with other vegetable yield (cucurbit, legumes and solanaceous crops) from 15 to $50 \mathrm{t} / \mathrm{ha}$ using common resources for 60 days in associa-

\footnotetext{
*For correspondence. (e-mail: myselfdebarati@gmail.com)
}

tion. In rabi rice-vegetable relay system, rice yield was 4.5 to $5.4 \mathrm{t} / \mathrm{ha}$ and that of cucurbit, it varied from 55 to $150 \mathrm{q} / \mathrm{ha}$, ginger $600 \mathrm{q} / \mathrm{ha}$, amorphophallus $120 \mathrm{q} / \mathrm{ha}$, and colocasia 20-25 tonnes tuber/ha. These vegetable crops generated additional income of Rs $0.5-4.50$ lakh/ha without hampering rice yield in between two rice crops, when this rice land usually remains fallow ${ }^{1-3}$. Under irrigated condition, cropping intensity of the traditional rice-rice cropping system (200\%) increased up to $400 \%$ ricevegetable-rice-vegetable system. It has been recorded that to diversify rice low lands in an economical manner, about 1500 to 5000 number of gunny bags weighing 750 to $2500 \mathrm{~kg}$ jute fibre will be consumed in one hectare area. Experiments were conducted over the years both at ICAR-CRIJAF and farmers' fields to diversify waterlogged rice fields, growing vegetables on gunny bag based soil columns as inter/relay crops to increase farmers' income, cropping intensity and establish the utility of gunny bags in agricultural fields, as a non-traditional sector.

Field experiments were conducted during kharif and rabi seasons from 2011 to 2017, at ICAR-CRIJAF, Barrackpore, West Bengal in randomized block designs (RBDs) replicated thrice. The soil of the experimental site was sandy-clay-loam in texture having $44 \%$ sand, $28 \%$ silt and $28 \%$ clay. Available nitrogen $(\mathrm{N})$, phosphorus $(\mathrm{P})$ and potassium $(\mathrm{K})$ content of the soil were 180,34 and $133 \mathrm{~kg} / \mathrm{ha}$ respectively. To validate the results, commercial trials were also conducted in different soils in different districts of West Bengal such as North 24 Parganas, Hoogly, Purba and Paschim Midanapur, Cooch Bihar, Murshidabad, Jhargarm, etc. with the help of Department of Agriculture, Government of West Bengal and different Farmers' clubs. The validity of the results was also tested in Odisha and Assam through ICARAINP JAF, Barrackpore.

For making soil reinforced jute columns and to suit different water depths in rice low lands, gunny bags (once used for rice sale) were cut into hollow columns of 11.25 to $45 \mathrm{~cm}$ height and $45 \mathrm{~cm}$ diameter. Jute hessians (180 to $230 \mathrm{GSM}$ ) were also cut into pieces of $85 \mathrm{~cm}$ in length and $30-45 \mathrm{~cm}$ in width. Both the cut ends at length were stitched together with jute thread and were given the hollow cylindrical shape having a radius of $13.5 \mathrm{~cm}$ and $30-45 \mathrm{~cm}$ height. These open ended gunny bags and meshy cylindrical hessians were soaked in systemic fungicide and pesticide solution for an hour to increase their longevity in waterlogged rice fields. These were fixed vertically on fertilized puddled soil by inserting 4-5 tough green jute sticks ( $45 \mathrm{~cm}$ length) and few strong bamboo pegs along their inner walls, which acted as pillars. After this, farmyard manure and fertilized puddled soils were filled alternately in four layers of equal depth in the gunny bag/jute hessian reinforced soil columns for healthy establishment of vegetable seedlings in these soil columns. Gunny bag/jute hessian reinforced soil columns 
were tied with their pillars using jute threads outwardly in circular fashion. The soil columns were left as such for 15 days for drainage of excess water from soil columns to create an aerobic zone above the puddled soil for easy growth and development of dicot vegetable crops (Figure 1). The row to row spacing between columns was $4 \mathrm{~m}$ and within the row, the column distances were $2 \mathrm{~m}$. For other crops the spacing was as usual in arable lands. Rice was transplanted after soil column preparation.

In kharif, 15 to 20 days after rice transplantation (1st to 2nd week of September), treated seeds of vegetable crops (bottle gourd, bitter gourd, pumpkin, cucumber, coriander, spinach and field beans, etc.) and seedlings (tomato, brinjal, cauliflower, cabbages) were planted on the soil columns (Figure 2). In rabi rice, cucurbits (pumpkin, ash gourd, sponge gourd, snake gourd, bottle gourd, etc.), solanaceous crops (brinjal and tomato), crucifers (cabbages, radish, cauliflower), coriander and ginger were sown on $30 \mathrm{~cm}$ to $45 \mathrm{~cm}$ height soil columns at 25 to 45 days after rice transplantation. Colocasia tubers and amorphophallus corm, ginger rhizomes, etc. were also sown in summer rice-relay, at 25 days after rice transplantation. To avoid waterlogging stress and for better economy from medium lands $(0-30 \mathrm{~cm}$ water $)$ over traditional rice cultivation in kharif, land transformation was made by developing $22.5 \mathrm{~cm}$ to $45 \mathrm{~cm}$ high gunny bag based soil columns where cabbage, cauliflower, Dioscorea alata, brinjal, parwal, sweet corn, etc. were grown as sole crops. In traditional rice-fallow areas, the saline rice
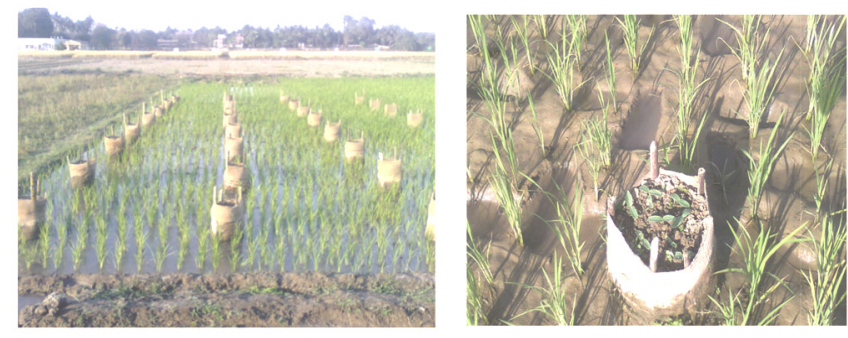

Figure 1. Gunny bag/jute reinforced soil columns in waterlogged rice field for vegetable cultivation avoiding anoxia.

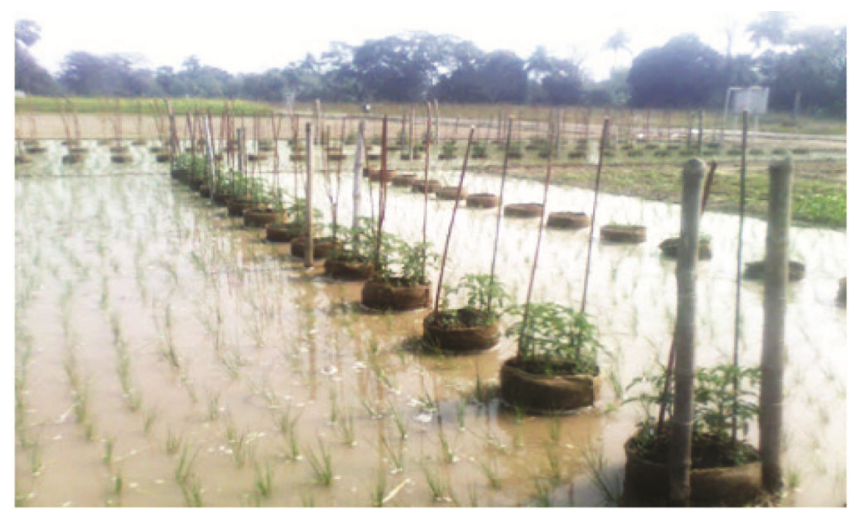

Figure 2. Tomato cultivation to diversify rabi rice field. fields were also diversified with gunny bag based soil columns to grow vegetables with rice in kharif season.

For healthy establishment of vegetables on soil columns, $100-200 \mathrm{ml} \mathrm{3 \%}$ mixed fertilizer ( $\mathrm{N}: \mathrm{P}: \mathrm{K}:$ : $10: 26: 26)$ solution and $2 \%$ urea solution were added alternately in each column at weekly intervals. Starting from planting of sprouted seeds/seedlings, the column soil surfaces were sprayed repeatedly with fungicides (Carbendazim, Mancozeb, Blitox, etc.) and systemic insecticides at weekly intervals to prevent seedling mortality and damage by fungus and insect attack. To avoid interference from rice plants, inverted umbrella type gabions were made around each column by inserting 6-8 ft long bamboo jute/sticks around the columns and the gabions were loosely knitted by jute fibres.

After rice harvest, the cucurbit twigs were trailed on ground and the vegetable crops were grown as per recommended management practices. For cucumber and field beans, scaffolds were made. Root system of the vegetables spread well on the uncultivated rice field even if the soil remained sticky after rice harvest. Irrigation and granular fertilizers (as per recommended dose) were applied directly in zero till situation immediately after

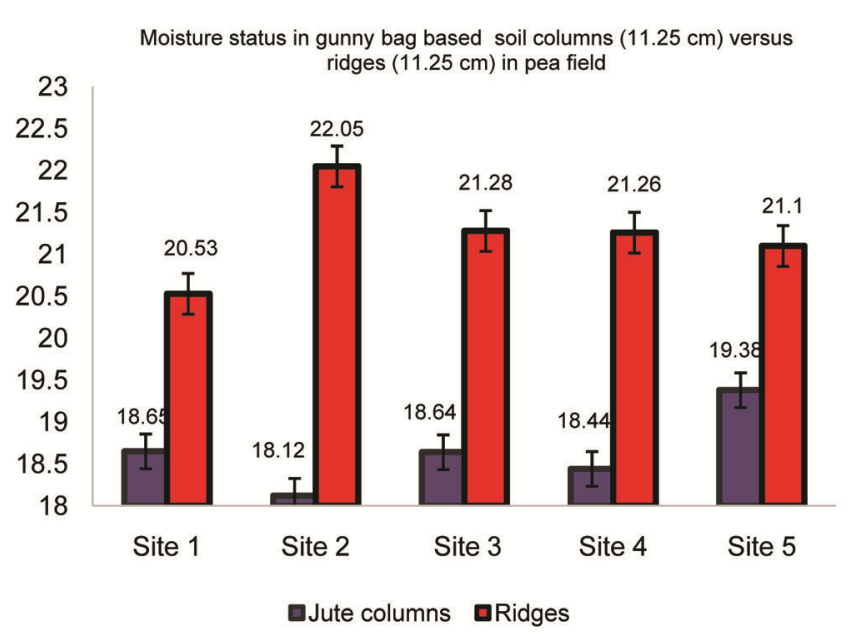

Figure 3. Moisture status in gunny bag based soil columns versus ridges in pea field during rabi season.

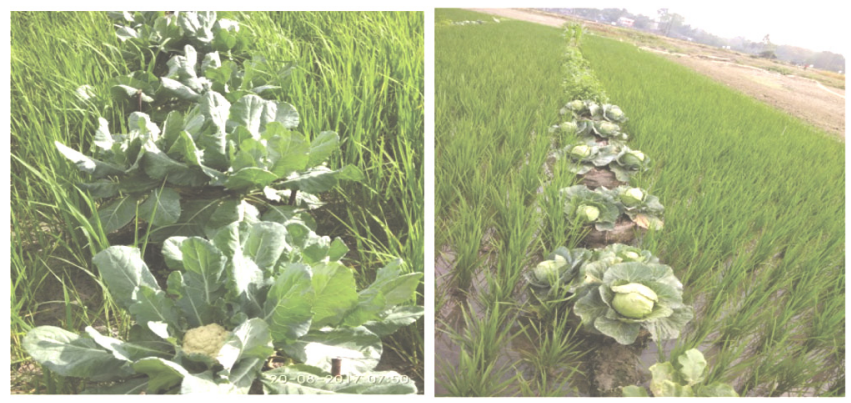

Figure 4. Cauliflower and cabbage as inter crop with rice on gunny bag soil columns. 


\section{RESEARCH COMMUNICATIONS}

Table 1. Vegetables production in kharif rice field in dual culture on medium land using gunny bag based soil columns and its economics

\begin{tabular}{|c|c|c|c|c|c|c|c|}
\hline Crops & $\begin{array}{c}\text { Jute } \\
\text { bags/ha }\end{array}$ & $\begin{array}{l}\text { Rice } \\
\text { yield } \\
(\mathrm{t} / \mathrm{ha})\end{array}$ & $\begin{array}{l}\text { Relay/inter } \\
\text { crop yield } \\
(q / h a)\end{array}$ & $\begin{array}{l}\text { Gross return from } \\
\text { relay/inter crops } \\
\quad(\mathrm{Rs} / \mathrm{ha})\end{array}$ & $\begin{array}{c}\text { Cost of cultivation } \\
\text { of relay/inter crops } \\
(\mathrm{Rs} / \mathrm{ha})\end{array}$ & $\begin{array}{l}\text { Net return from } \\
\text { relay/inter crops } \\
(\mathrm{Rs} / \mathrm{ha})\end{array}$ & $\begin{array}{c}\text { Return } \\
\text { per unit cost } \\
(\mathrm{Rs} / \mathrm{Rs})\end{array}$ \\
\hline Pumpkin & 412 & 3.0 & 173 & 208,000 & 50,282 & 157,718 & 4.14 \\
\hline Bottle gourd & 412 & 3.0 & 210.46 & 315,633 & 55,173 & 260,460 & 5.71 \\
\hline Bitter gourd & 827 & 3.0 & 24.80 & 124,000 & 50,121 & 73,879 & 2.47 \\
\hline Arhar & 1046 & 3.0 & 18.82 & 90,352 & 57,693 & 32,659 & 1.57 \\
\hline Ginger & 1046 & 3.0 & 9.93 & 59,600 & 87,653 & $-28,053$ & 0.68 \\
\hline Radish & 1046 & 3.0 & 24.0 & 48,000 & 39,601 & 8,399 & 1.21 \\
\hline Kharif spinach & 1046 & 3.0 & 26.14 & 52,280 & 36,601 & 15,679 & 1.32 \\
\hline White amaranth & 1046 & 3.0 & 78.42 & 47,052 & 36,601 & 10,451 & 1.28 \\
\hline Brinjal & 1046 & 3.0 & 125 & 125,000 & 81,101 & 43,899 & 1.54 \\
\hline $\mathrm{CD}(5 \%)$ & - & - & 29.49 & 42,050 & 7,600 & 41,690 & 0.60 \\
\hline
\end{tabular}
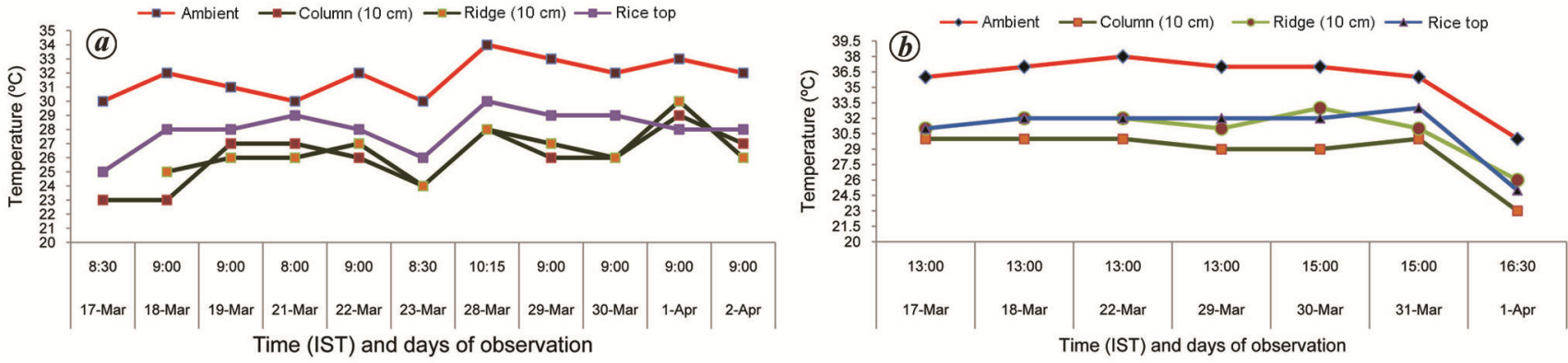

Figure 5. $\boldsymbol{a}$, Desirable soil temperature of columns during morning hours for optimum development of carrot in summer. $\boldsymbol{b}$, Desirable soil temperature of columns during noon hours for optimum development of carrot in summer.
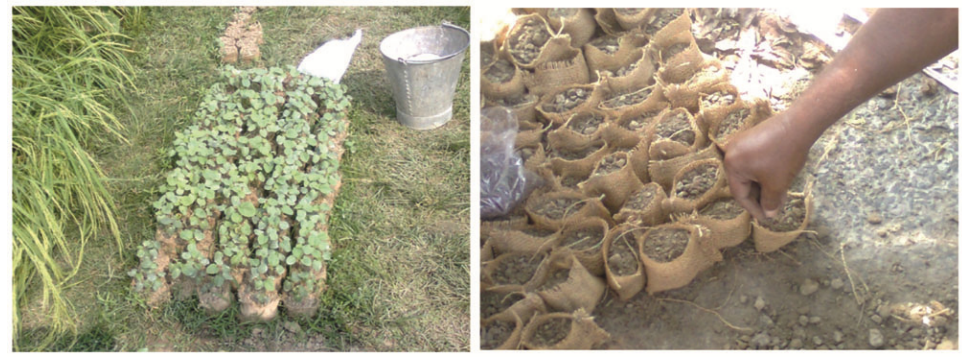

Figure 6. Readymade winter okra and mustard seedlings in jute packets for sequential planting in rice-relay system.

rice harvest. In summer rice-vegetable relay, the cucurbits were grown on scaffolds to avoid fruit rot by soil contact.

To grow pumpkin, bottle gourd and field beans in rice field, around 1250 columns/ha are required which costs around Rs 18,750/ha only@ Rs 15/column. In conventional sole vegetable production in low rice lands sacrificing rice crops, on mega ridges $(1 \mathrm{~m}$ base width $x$ $50 \mathrm{~cm}$ height, at a spacing of $1 \mathrm{~m}$ ), the cost involved to transform the rice field is around Rs 40,000/ha. Cucurbits of each column were allowed to grow in an area of $8 \mathrm{~m}^{2}$ land only. For easy movement and intercultural operations of vegetable crops in rice field, rice transplantation along the columns should be skipped which is an established recommendation to minimize pest and disease attack in rice fields, especially for brown planthopper.
Loss of rice area in this process will be around $625 \mathrm{~m}^{2} /$ ha (6.25\% of a hectare) which sacrifices around 3 quintal raw rice/ha considering the total rice yield as $5 \mathrm{t} / \mathrm{ha}$. Water productivity of rice field is obviously high as remunerative vegetables are grown together.

The columns remained stable up to eight months in rice field. The hydrograph of ponding ranged between $0 \mathrm{~cm}$ and $30 \mathrm{~cm}$ during rice growth. The oxygen diffusion rate of gunny bag/hessian reinforced soil columns (up to $15 \mathrm{~cm}$ depth) was more than two times $\left(280 \mu \mathrm{g} / \mathrm{m}^{2} / \mathrm{sec}\right.$, ODR Meter, Eikjelkamp, The Netherlands) the conventional ridges $\left(115 \mu \mathrm{g} / \mathrm{m}^{2} / \mathrm{sec}\right)$. The moisture content of these soil columns varied from $18.5 \%$ to $19.38 \%$ over $20.53 \%$ to $22.05 \%$ in conventional ridges (Figure 3 ). Thus gunny bag/hessian reinforced soil columns maintained better air and moisture regime in rhizosphere over 


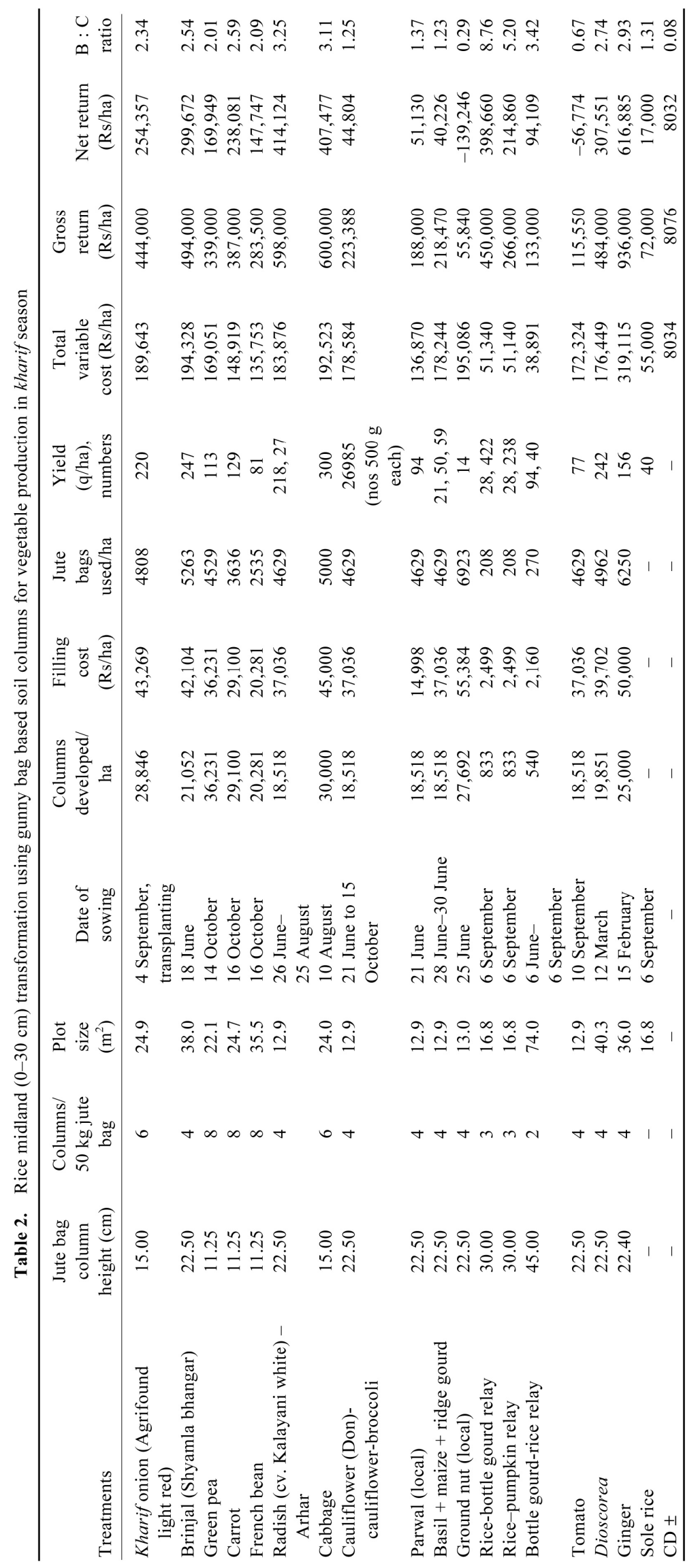


RESEARCH COMMUNICATIONS

Table 3. Additional vegetables production from rabi rice field as intercrop using gunny bag based soil columns and its economics

\begin{tabular}{|c|c|c|c|c|c|c|c|}
\hline Crops & $\begin{array}{l}\text { Jute bags } \\
\text { used/ha }\end{array}$ & $\begin{array}{c}\text { Rice yield } \\
(\mathrm{t} / \mathrm{ha})\end{array}$ & $\begin{array}{l}\text { Relay/inter } \\
\text { crop yield } \\
(\mathrm{q} / \mathrm{ha})\end{array}$ & $\begin{array}{l}\text { Gross return from } \\
\text { relay/inter crops } \\
(\mathrm{Rs} / \mathrm{ha})\end{array}$ & $\begin{array}{c}\text { Cost of cultivation } \\
\text { of relay/inter crops } \\
(\mathrm{Rs} / \mathrm{ha})\end{array}$ & $\begin{array}{l}\text { Net return from } \\
\text { relay/inter crops } \\
\qquad(\mathrm{Rs} / \mathrm{ha})\end{array}$ & $\begin{array}{c}\text { Return per } \\
\text { unit cost } \\
(\mathrm{Rs} / \mathrm{Rs})\end{array}$ \\
\hline Cabbage & 12405 & 4.5 & 51 & 51133 & 39818 & 11,315 & 1.28 \\
\hline Brinjal & 12405 & 4.5 & 152 & 150000 & 66316 & 83,684 & 2.26 \\
\hline Carrot & 12405 & 4.5 & 28.3 & 42500 & 36816 & 5,684 & 2.80 \\
\hline Tomato & 12405 & 4.5 & 69 & 103000 & 37316 & 65,584 & 0.30 \\
\hline Onion & 12405 & 4.5 & 12.3 & 11333 & 33316 & $-21,983$ & 0.34 \\
\hline Chilli & 12405 & 4.5 & 11.8 & 35400 & 36316 & -916 & 0.97 \\
\hline Cauliflower & 12405 & 4.5 & 29 & 29000 & 36316 & $-7,316$ & 0.80 \\
\hline Coriander & 12405 & 4.5 & 9.3 & 46500 & 36316 & 10,184 & 1.28 \\
\hline Radish & 12405 & 4.5 & 33 & 50000 & 36311 & 13,689 & 1.38 \\
\hline $\mathrm{CD}(5 \%)$ & NS & NS & 5.60 & 7343 & 7495 & - & 0.31 \\
\hline CV (\%) & - & - & 7.37 & 9.74 & 10.86 & - & 14.21 \\
\hline
\end{tabular}

conventional ridges during the growth period of vegetables.

Different cucurbits, field beans and solanaceous vegetable crops grew well on jute reinforced soil columns (Figure 1) and produced higher yields. In rice-vegetable relay system, the rice yield varied from 3 to $4 \mathrm{t} / \mathrm{ha}(\mathrm{cv}$. Banskati and Satabdi), followed by vegetable yield of 15 to $50 \mathrm{t} / \mathrm{ha}$. From rice field, as off season intercrop, spinach, coriander, radish, cauliflower and cabbages were harvested within 45-90 days of sowing from soil columns and yielded 24-25 quintal (q) fresh vegetables per hectare (Tables 1 and 2, Figure 4). Brinjal and tomato yield varied from 200 to $300 \mathrm{q} / \mathrm{ha}$. These vegetable crops generated an additional income of Rs 0.5 to 3.0 lakh/ha without hampering rice. In transformed rice midlands, using gunny bag soil columns, yield of kharif onion, cauliflower, cabbage, parwal, brinjal, tomato, dioscorea and ginger were $220,135,300,94,247,77,242$ and $156 \mathrm{q} /$ ha respectively (Table 2). Similar responses were also obtained over the years from farmers' fields and the technology is being disseminated by the Department of Agriculture, Government of West Bengal through different projects like ATMA and different farmers' clubs of West Bengal.

The hydrograph of ponding in rabi rice varied from 0 to $5 \mathrm{~cm}$ during rice growth period. In this system, $4.5 \mathrm{t} / \mathrm{ha}$ rice along with late cabbage (51 q), carrot $(28.3 \mathrm{q})$, brinjal (152 q), tomato (69 q), coriander $(9.3 \mathrm{q})$, onion (12.3 q), summer radish (33 q) and chilli (11.8 q) were harvested (Table 3 ). Highest gross return and return per unit cost were obtained from brinjal, carrot, cabbage, coriander and radish. In hot summer, the temperature inside the rice canopy and soil columns $(10 \mathrm{~cm}$ depth $)$ was lower by $3-9^{\circ} \mathrm{C}$ compared to ambient temperature. The lower column temperatures facilitated development of fleshy roots of summer radish and carrot (Figure 5). Lower rice canopy temperature helped in better setting of tomato fruits in hot summer and increased shelf life and freshness of ripened tomato fruits, cabbage and coriander. Cucurbit yields in summer rice-relay system varied from 55 to $150 \mathrm{q} /$ ha, ginger $600 \mathrm{q} /$ ha (single rhizome cluster was up to $4.5 \mathrm{~kg} / \mathrm{ha}$ ), amorphophallus $120 \mathrm{q} / \mathrm{ha}$ and colocasia yielded 20-25 tonne tuber/ha along with 4.5 tonne summer rice/ha. This process consumed about 1125 gunny bags/ha (50 kg capacity, weighing 7 q jute fibre). Similar results were also recorded from farmers' fields.

To address the issue of soil salinity $\left(1.69 \mathrm{dSm}^{-1}\right)$ at Najat, Sandeshkhali-1, North 24 Parganas, soil columns $(45 \mathrm{~cm} \times 45 \mathrm{~cm})$ were also developed in saline rice soils in farmers' fields in kharif rice-vegetable relay system, with the help of the Department of Agriculture, Government of West Bengal. The soluble chloride and sulphate salts of $\mathrm{Na}, \mathrm{Ca}$ and $\mathrm{Mg}$ from the soil of the columns were washed away by rain and thus created a favourable environment for easy establishment of vegetables in rice field, avoiding salinity stress. The vegetable crops matured well before the rise of saline salts in summer months (AprilMay) through capillary rise in upper soil layer and thus escaped the salinity problems. The vegetable (different cucurbits and tomato) yield ranged between 15 and 20 t/ha along with 3-5 tonne rice/ha. Two hundred per cent cropping intensity was established over $100 \%$ cropping intensity in traditional rice-fallow system, avoiding salinity stress.

To cope with late harvest of rice and timely planting of sequential crops under waterlogged muddy condition, 2025 days old established field crop (mustard, etc.) and vegetable (cucurbits, okra, raj mash) seedlings (developed in small jute bags, $10 \mathrm{~cm} \times 7-10 \mathrm{~cm}$, Figure 6) were found effective which increased the cropping intensity of low lands. These crops escaped cool temperatures and performed well in winter season ${ }^{4}$. In this ricevegetable relay, $28 \mathrm{q}$ mustard, $40 \mathrm{q}$ round bitter gourd, $40 \mathrm{q}$ raj mash, $35.8 \mathrm{q}$ cucumber and $65 \mathrm{q}$ winter okra per hectare (November-May) were harvested.

For wasteland management (having no groundwater contribution), a system was simulated on brick lined floor, developing gunny bag based soil columns $(22.5 \mathrm{~cm}$ height $\times 45 \mathrm{~cm}$ diameter) over it. Selected crops were sown in early August on columns and were harvested after maturity. We successfully harvested sweet corn 
(32,000 cobs/ha), radish (128 q/ha), vegetable brassica (130 q/ha), spinach (40 q/ha) and pumpkin (182 q/ha) $(45 \mathrm{~cm} \times 45 \mathrm{~cm}$ columns, having pitcher within the columns). Crops were successfully grown under rainfed conditions with two-three additional irrigation as drought prevailed during entire September. Herein, 4000 jute bags were used in one hectare land.

1. Ghorai, A. K., Kundu, D. K., Satpathy, S. and Ghosh, R., Crop diversification in anaerobic rice field using gunny bag reinforced soil columns. SAARC AgriNews, 2014, 8(2), 7-8.

2. Ghorai, A. K., Chowdhury, H., Kundu, D. K. and Kumar, S., Use of gunny bag and jute fabrics in agricultural field (Krishi Kshetro mein patsan boro abong bistro ka prayog). Kheti, 2016, 11, 30-32.

3. Ghorai, A. K., Kundu, D. K., Shailesh Kumar and Shamna, A., Use of gunny bags/jute fabrics in agricultural field for sustainable family farming for food, nutrition and livelihood security. In book (eds Mondal, B. et al.), Renu Publishers, New Delhi, 2016, pp. 107110 .

4. Crop management: Crop diversification in waterlogged rice field. DARE Annual Report, 2012-2013, p. 44.

ACKNOWLEDGEMENTS. We acknowledge the Director, ICARCRIJAF for providing financial help and constant support for conducting the field experiments and extension trials in different districts between 2011 and 2017. We also acknowledge the help of Department of Agriculture, Government of WB, different farmers' clubs and ICARAINP JAF for their help in the dissemination of our technology in different places.

Received 2 July 2020; revised accepted 23 July 2020

\section{Grassland productivity during early winter in Ladakh, India}

\section{R. K. Sawal*, Rakesh Ranjan, Kashinath and Radha Krishan Verma}

ICAR-National Research Centre on Camel, Bikaner 334 001, India

Agro-pastoralism is the backbone for the sustenance of livelihood of people in semi-arid mountainous deserts of Ladakh, India. Livestock comprising sheep, goat, yak, donkey and horse, play an important role in human survival by providing fuel, transport, wool, milk, organic manure, meat and hide. Deficiency of fodder is the major constraint in livestock production system in this area; hence grassland vegetation avail-

*For correspondence. (e-mail: rksawa101@gmail.com) able for grazing is important for livestock feeding and nutrition. The present study was aimed to evaluate grassland productivity in different villages of Leh, Ladakh. Productivity of grasslands in the study area ranged from 0.7 to $8.8 \mathrm{q} / \mathrm{ha}$, reflecting low values and wide variability. Nutrient availability in grasses was poor, while fibre content was high. Supplementation of feed, fodder or concentrate ration is therefore essential to meet the nutritional requirements of the livestock largely dependent upon grazing in those grasslands.

Keywords: Agro-pastoralism, early winter, grassland productivity, livestock, nutrient availability.

TOPOGRAPHY of Ladakh, India is characterized by undulating terrain interspersed with rocky hills and elevation ranging from 4500 to $5880 \mathrm{MSL}$. In addition, due to the extreme cold, aridity, high radiation and strong winds, majority of Ladakh's landscape is more suitable for livestock husbandry than crop cultivation. Therefore, livestock husbandry is the main livelihood of Ladakh with the livestock population nearly 3.3 times the human population ${ }^{1}$. For centuries, agro-pastoralists in Ladakh have produced the finest pashmina wool apart from meat, dairy products and organic fertilizers.

Grazing resources are limited to areas along water bodies like reservoirs, rivulets and rivers. Grass cover along the river bank is the main food source available for livestock in the region. Due to low precipitation, plant productivity is very low ${ }^{2}$. The growing season is confined to short-duration species grown during June to August in summer, and vegetation is characterized by alpine steppe communities with medium to sparse cover (20\%); the dominant gross species include Carex and Stipa grass species. Availability of grass cover has been found to be $40-70 \%$ deficient in cold arid regions ${ }^{1}$. Nevertheless, domesticated animals with the exception of donkeys and horses usually spend the summer grazing in highelevation pastures and small grasslands. Therefore, estimation of grassland productivity and nutritional quality assessment of the available grasses could help evaluate sustainability of livestock in the Ladakh region.

Random samples of vegetation from the grazing areas in the villages of Thang (Sub-division Nubra, Block Turtuk), Hundar (Sub-division Nubra, Block Diskit), Suspol (Sub-division Likir, Block Saspol), Nimoo (Subdivision Likir, Block Nimoo), Likir (Sub-division Likir, Block Nimoo) and Yakma Chuchot (Sub-division Leh, Block Chuchot) in Leh district, Ladakh were collected during October 2019. In each village, 10 quadrants of $1 \mathrm{~m}$ each from different grassland sites used for livestock grazing, largely along the river bank or natural water channel side were selected. Samples of the grass cover were clipped $1 \mathrm{~cm}$ above the ground from area under the quadrant and stored in brown-paper envelopes. Thereafter, the samples were transported to the ICAR-National 